\title{
LOST TO FOLLOW-UP : REASONS AND TRUE OUTCOME FOR PATIENTS ON ARV TREATMENT IN TERATAI CLINIC BANDUNG INDONESIA
}

\author{
Hartiah Haroen $^{1}$, Tita Sri Puspitasari ${ }^{2}$, B.Van Den Borne ${ }^{3}$, Citra Windani Mambang Sari ${ }^{4}$ \\ ${ }^{1,2,4}$ Faculty Of Nursing Padjadjaran University \\ ${ }^{3}$ Maastricht University \\ Email : ${ }^{4}$ nurse_citra@yahoo.com
}

\begin{abstract}
ABSTRAK
Klinik RSHS Teratai HIV telah merawat pasien dari September 2004 sampai Desember 2009, sebanyak 2.060 ODHA dan 1290 menerima ARV (63\%). Selama periode ini, sebesar 11\% (141 orang) kehilangan kontak lebih tinggi dari keseluruhan persentase di Indonesia yaitu 10,7\% (Depkes, 2009). Tujuan dari penelitian ini adalah untuk menyelidiki hasil yang benar dan faktor hilang tindak lanjut ARV di klinik RSHS Teratai ARV. Penelitian ini menggunakan metode wawancara mendalam dengan 25 pasien HIV / AIDS bawah pengobatan ARV di klinik Teratai RSHS dan mangkir sejak tahun 2009 yang tinggal di daerah Bandung. Informan dipilih secara acak dan dihubungi untuk kunjungan rumah untuk diwawancarai oleh pewawancara yang berpengalaman. Peneliti melakukan wawancara mendalam di rumah pasien sekitar 60 menit. Data direkam oleh pita digital direkam, ditranskrip dan dicetak oleh dua peneliti bidang independen menggunakan analisis tematik.Hasil penelitian ini menunjukkan tujuh tema yang pengetahuan yang tidak benar, optimisme yang tidak realistis, masalah aadministratif, perasaan efek samping negatif, masalah interpersonal, masalah kecanduan, dan kurangnya perawatan diri. Oleh karena itu, penting untuk mengembangkan tindakan pencegahan melalui rincian kontak pasien, meminta pasien persetujuan untuk dihubungi, telepon, kunjungan rumah setelah 3 minggu kehilangan kontak, dan menyarankan pasien untuk mendaftar ke klinik ART lebih dekat dengan rumah mereka, dan mengembangkan sistem reminder untuk mengingatkan pasien untuk mengambil ARV tepat waktu.
\end{abstract}

Kata kunci: ARV, hilang tindak lanjut, pasien HIV/AIDS

\begin{abstract}
Teratai clinic HIV RSHS has treated patients from September 2004 to December 2009, as much as 2060 PLWHA and 1290 receive ARV (63\%). Over this period, 11\% (141) were lost to follow-up that is higher than overall lost to follow up percentage in Indonesia which is 10.7\% (MOH annually report December 2009). The aim of this study was to investigate the true outcomes and factors of lost follow up to ARV. This study used indepth interview method to 25 HIVIAIDS patients under ARV treatment in the Teratai clinic RSHS and lost to follow up since 2009 who lived in Bandung area. Informants were randomly selected and contacted for a home visit to be interviewed by experienced interviewer. The interviewers obtained verbal informed consent and conducted an in depth interview in the patients home. Interview took about 60 minutes. Data were recorded by digital tape recorded, transcribed and scored by two field researchers independently using thematic analysis. The result of this study shows seven themes which are incorrect knowledge, unrealistic optimism, administrative problems, feeling of negative side effect, interpersonal problem, addiction problem, and lack of self-care. Therefore, it is important to develop preventive measure through up-dating patients' contact details, ask patients consent to be contacted, up date phone contact, home visit after 3 weeks lost of contact, advice patients to register to ART clinic closer to their homes, and develop a reminding system to remind patients to take ARV on time.
\end{abstract}

Keywords: ARV, HIV/AIDS patients, lost to follow up 


\section{INTRODUCTION}

The recent years the HIV prevalence in Asian countries such as Thailand, Cambodia, and Myanmar have declined. Despite that, Indonesia currently is still one of the fastest growing epidemics in Asia (UNAIDS 2007 and UNGASS report 2008). There are around 19,973 people living with HIV and AIDS (PLWHA) in Indonesia from the total population of 230,632,700 (Indonesian Bureau of Statistic, 2009).

The Directorate of General Communicable Disease Centre and Environmental Health of Indonesian Ministry of Health HIV/AIDS reported West Java have 3598 cases $(18 \%)$ to be provinces with the highest numbers followed by East Java, 3227 (16\%) and DKI Jakarta, 2828 cases (14\%) (Desember, 2009). From October 2008 to December 2009 there were 285 new cases reported in West Java; which caused the region to be the highest of new cases reported in Indonesia. More than half of the cases were in Bandung, the capital city of West-Java (Directorate General CDC\&EH Ministry of Health, 2008; 2009).

The growing number of people living with HIV/AIDS is a serious concern for the Indonesian government. Various treatment and care programs have been implemented in every level of health care setting from hospitals to community health centers. According to the National AIDS commission (NAC), the comprehensive care includes prevention, support for prevention of future transmission, voluntary counseling and testing (VCT), follow-up counseling, prevention and treatment of opportunistic infection and provision of ARV (National AIDS commission, 2008).

Anti Retro Virus (ARV) has been proven effective to increase CD4 levels, suppress HIV viral load and improve patients' quality of life (Nachega; Mugavero; Zeier; Vitória, Gallant, 2011). From this research, ARV resulting a decrease in the morbidity and mortality of HIV/AIDS patients. ARV has been implemented in Indonesia since 2005, but only $30 \%$ of HIV/AIDS patient has access to the treatment in Indonesia (WHO, 2008). Therefore the coverage of ARV in Indonesia is still need to expand.

Adherence is a key factor in the success of ARV treatment (Mills et al., 2006 and Nachega, 2011). Patients who received ARV therapy need to adhere to take the medicine regularly and with the right dose, and they have to take this treatment for the rest of their life in order to inhibit the progression of the disease and prevent development of opportunistic infections. A minimum adherence of $95 \%$ of the prescribed-dose taken is needed to suppress the virus optimally, and failure to do so can cause virology failure (Bangsberg et al., 2004 and WHO, 2007). Low adherence of ARV is related to complexity of ARV regiment and its side effects which could lead to high incidence of patients' lost to follow up.

Lost to follow up is a condition in which HIV/AIDS patients drop out from ARV treatment. Lost to follow up coupled with poor service utilization can dramatically limit the population coverage of HIV/AIDS treatment programs (Hutchinson et al 2006). Preventive measures need to be incorporated into the ARV treatment protocol and system to increase retention rate. Common reasons for not returning the clinic to take ARV are transfer to another program, financial problems, improving or deteriorating health and death (Brinkhof, Rodrigues and Egger, 2009).

ARV service in Bandung Indonesia is currently being provided in selected hospitals such as Hasan Sadikin Hospital (RSHS) as the top referral hospital in Bandung, the capital city of West Java (population 42 million). The RSHS Teratai HIV clinic has treated patients from September 2004 to December 2009, as much as 2060 PLWHA and 1290 receive ARV (63\%). Over this period 16\% (678) were active on treatment, $19 \%$ (249) died, 16\% (206) moved to other ARV clinics, $11 \%$ (141) were 
lost to follow-up and 1\% (16) stopped receiving ARV (Teratai clinic, 2010). The percentage of lost to follow up patient is Teratai clinic Bandung (11\%) is higher than overall lost to follow up percentage in Indonesia which is $10.7 \%$ ( $\mathrm{MOH}$ annually report December 2009). In order to improve services, this study aims to investigate the true outcomes and factors of lost follow up to ARV, in the RSHS Teratai ARV clinic.

\section{Objectives}

To identify true outcomes and reasons of lost to follow up of patients receiving ARV treatment in the RSHS Teratai clinic.

\section{METHODS}

HIV/AIDS patients under ARV treatment in the RSHS/Teratai clinic and lost to follow up since 2008 who lived in Bandung area were identified and listed. Home visit were conducted to all patients, 25 patients were randomly selected and contacted for a home visit in order to be interviewed by experienced interviewers. The interviewers obtained verbal informed consent and conducted an in depth interview in the patients home. Interview took about 60 minutes. Data were recorded by digital tape recorded and transcribed. The transcript read and scored by two field researchers independently using thematic analysis. Findings will be discussed and compared to develop a more complete understanding of the data that has been collected. Data were recorded by digital tape recorder and transcribed into Indonesian. Notes and observations also recorded at the time of the interview by the interviewer.

\section{Study population}

Population for this study is 141 patients Lost to follow up Patients of Teratai clinic Hasan Sadikin Hospital Bandung West-Java who lives in Bandung.

\section{Number of Subject}

Subject for this study 25 patients were randomly who meet the inclusion criteria will be included in the study; Interview will be stopped if there were no new information emerged. Criteria of Inclusion of PLWHA : adult patient, age $21-45$ years old, registered in Teratai data between period 2005-2009, have misses receiving ARV in at least 3 consecutive months during the period of treatment, patients who have history of missing receiving ARV at least 3 consecutive during the period of treatment, reside in Bandung City region, agree to participate in the study. Criteria of Exclusion : patients who moved to outside Bandung, patients who refuse to participate in the interview, patients who move to new treatment site (hospital/clinic)

\section{RESULTS}

\section{Reasons of ARV Default in Clinic Teratai, Hasan Sadikin Hospital Bandung}

The success of Anti Retroviral Therapy was depending on patients' adherence toward dosage and time of taking ARV. Non adherence would lead to ARV default which could give negative impact toward health condition of PLWHA and HIV/AIDS treatment.

Since 2004 to December 2009, Teratai Clinic - Hasan Sadikin Hospital has been serve 1290 patients with ARV. From 2007 until end of 2010 there were 141 patients that did not came back to the clinic to take ARV (lost to follow up). The highest proportion of lost to follow up patients is in 2009 as much as $43 \%$. Percentage of lost to follow up patients slightly decreased in 2010 just $30 \%$ from overall patients. The complete data could be seen in Figure 1. 
Figure 1: Proportion Patients Lost to Follow Up based on the Last Year Taking ARV in Teratai Clinic

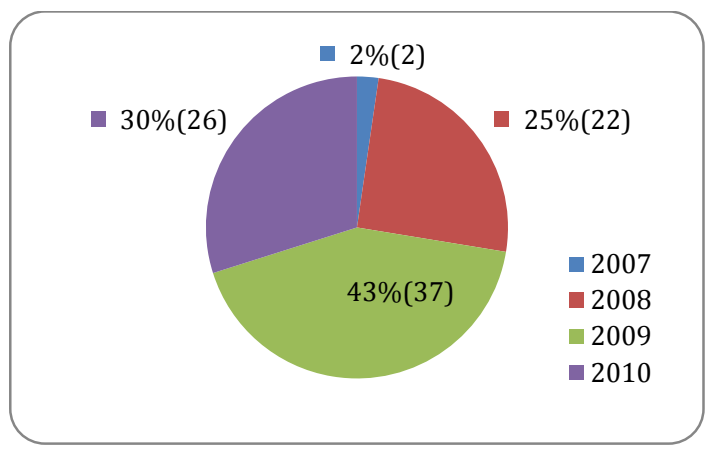

The result of home visit showed that overall $59 \%$ patients really lost to follow because of, giving false address, incomplete address and moving out without giving information of new addres which is $26 \%, 16 \%$ and $14 \%$ respectively. As much as $14 \%$ patients died and 14\% referred to hospital. Only $13 \%$ of lost to follow up patients that can be interviewed in home visit.

Figure 2. Result of Home Visit for Lost to Follow Up Patients $(\mathrm{N}=87)$

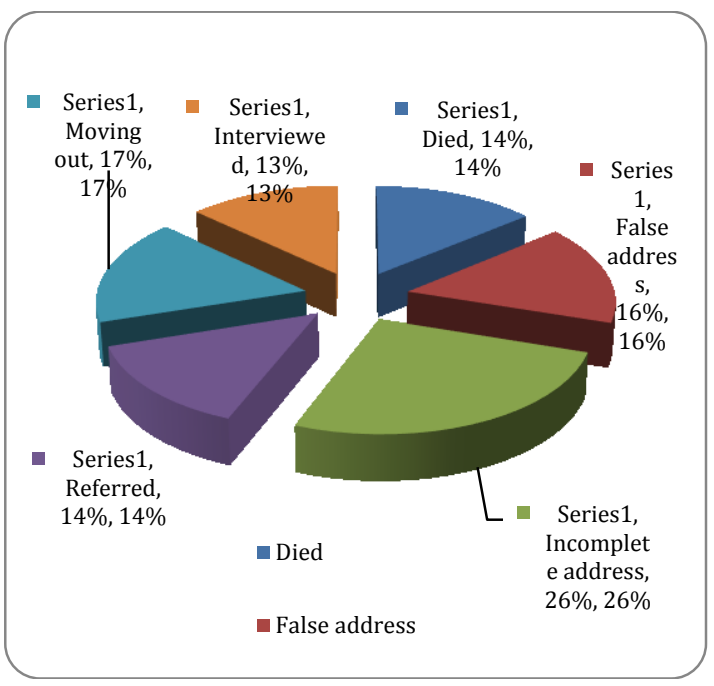

From the interviews, it can be inferred that reason of lost to follow up from patients are: 1) No health problem. Three of 11 patients said that they do not have health problem even though they stopped taking ARV medicine. They said that as long as they keep eat healthy food and do regular exercise they would stay healthy without taking ARV. 2) Two patients stop taking ARV because they use traditional medicine. 3) Two patients did not have time to take the medicine regularly every month because they work outside Bandung (Banten and Kalimantan). 4) Five patients felt ashamed and uncomfortable if they have to take the medicine in Teratai Clinic again because often lateness. 5) One patients has married again and has not opened her status to new husband so that she afraid that her husband would know her condition. 6) Three patients did not have money for transportation to and from clinic, and social network service has not implemented very well.

Reasons of Lost to follow from the 5 interviews were : 1) Incorrect knowledge : Believe that if stopping ARV for three months means cannot continue or start ARV again, Believe that traditional remedy can also cure HIV/AIDS (Mahkota dewa). 2) Unrealistic optimism : Believe that with practicing healthy life such as eating well, exercise regularly and traditional remedy will cure HIV/AIDS, did not feel any negative or bad symptoms when stop taking ARV (2 patients).

3) Administrative Problems : Think that the clinic's administration was too complex (patients used to register in the general admission office then referred to Teratai clinic. They had to be in the very long queuing). Lack of information that HIV/AIDS patient can register straightly into Teratai Clinic. 4) Feeling of negative side effect when taking ARV: patients could not concentrate and focus in his daily activity. 5) Interpersonal problem with health care personnel (self problem). One patient disappointed with the health care personnel attitude just because of he came late for taking ARV, from then he did not want to come to the clinic anymore. 6) Addiction problem: one patient stated that ARV useless without Andep. He stopped come to the clinic because of disappointed with doctor who did not prescribed. 7) Lack of selfcare : ignorance to the condition and self health.

\section{DISCUSSION}


This study shows that more than half of the patients receiving ART who were lost to follow up were untraceable because of false or incomplete address and moving to other city. The reason of this condition is not clear whether patients purposely giving wrong or incomplete address to clinic register or whether the details collected by clinic register were incomplete or unclear due to lack of time of registration or other reason. Some patients had been deceased, but the reason for death could not be identified. About one quarter was alive, some are referred to hospital, some were taking ARV in other clinic, and only few patients can be interviewed (13\%). The reason of lost to follow up including incorrect knowledge about ARV treatment, unrealistic optimism, administrative problem, negative side effect, interpersonal problems, addiction problem and lack of self-care. These overall conditions are similar to study from Weigel et al (2011) from Malawi that explain important lesson from lost to follow up study in Malawi which is correct address very important to be recorded in ARV clinic, immediate follow up needed to be done for patients who stop taking ARV medication. The clinic should consider advising patient to find ARV clinics or support that easy to access in order to prevent patients moving from one clinic to another.

Efforts to trace HIV/AIDS patients that lost to follow up is very important to evaluate the program and increase quality of care towards HIV/AIDS patients. In Teratai Clinic RSHS Bandung 11\% were lost to follow up. From the study sample only $13 \%$ of lost to follow up patients can be traced and interviewed. Among patients who can be interviewed none have still taken ARV. This result is in accordance of study from Brinkhof, Rodrigues, and Egger (2009) that showed common reasons for not returning the clinic to take ARV are transfer to another program, financial problems, improving or deteriorating health and death. Another study by Micek et al. (2009) in developed countries also shows that follow-up with chronic care is also influenced by "the perceived need for treatment, satisfaction with care, and the quality of provider-patient relationships. Stigma, an unfamiliarity with chronic care, limited human resource capacity, a cumbersome pre-ART preparation process, and transportation as additional factors".

The result of LTFU in Teratai Clinic RSHS studies shows that the knowledge and understanding of HIV/AIDS patients about ARV is still low. Lack of knowledge could lead to low adherence and further could increase the risk of resistance for the ARV. A minimum adherence of $95 \%$ of the prescribeddose taken is needed to suppress the virus optimally (Bangsberg et al., 2004 and WHO, 2007). Adherence is a key factor in the success of ARV treatment (Mills et al., 2006 and Witteveen, 2002). Short follow-up time on ART also become the stronger predictor of death which $50 \%$ to $65 \%$ mortality in patients with no follow up visit or last visit in the first six month (Weigel at al. 2011). In other study also showed that mortality rate was 115,42 and 21 per 100 person per years after 1, 2 to 6 , and after 6 months since the last visit, respectively (Geng et al. 2009). These findings shows that an earlier start of active follow up patients could decrease early mortality rate.

Other reason of lost to follow up from the interviewed are that some patients experience admininstration and interpersonal problem which is lack of knowledge of registration process and poor attitude of clinic personel. Lost to follow up coupled with poor service utilization can dramatically limit the population coverage of HIV/AIDS treatment programs (Hutchinson et al 2006). Preventive measures need to be incorporated into the ARV treatment protocol and system to increase retention rate. Preventive measure that can be done is regular ascertainment of patients' contact information at the first clinic visit, ask patients consent to be contacted, up date phone contact, and advice patients to register to ART clinic closer to their homes (Weigel et al. 2011). Phone contact is more 
effective than infield tracing, however on the phone patients might not reveal the truth, or they have changed the phone number because as many reason. The period of LTFU patients to be traced is 3 weeks from their last schedule (Weigel et al. 2011). Another adherence support strategy including pre-ART counseling visit, community-based groups in adherence support, treatment partners, giving modified directly observed therapy ang tracing patients who did not refill medication (Micek et al. 2009).

\section{CONCLUSIONS}

In conclusion, more than half people living with HIV/AIDS who were lost to follow up have been untraceable because of incomplete or false address and move to other city. Recomendation that could be suggested from this study are: 1) Patients is given information about closest ARV clinic to patients home or workplace. 2) Up-dating information of patients' address, phone number, or other phone number that could be contacted in case the patients' did not come to the clinic to take ARV. 3) It is important to develop a reminding system for patients to take ARV in Teratai clinic through short message service or direct phone, and also home visit.

\section{REFERENCES}

Chenard C (2007). The Impact of Stigma on self-care Behaviour of HIV-positive gay men striving for normalcy. Journal of the Association of Nurses in AIDS Care;18(3):23-32.

Geng EH, Bangsberg DR, Musinguzi N, Emenyonu N, Bwana MB, Yiannoutsos CT, et al (2009). Understanding Reasons for and Outcomes of Patients Lost to Follow$\mathrm{Up}$ in Antiretroviral Therapy Programs in Africa Through a Sampling-Based Approach. J Acquir Immune Defic Syndr 2009,53:405411
Chou F and Holzemer (2004). Linking HIV/AIDS Client's self care outcomes. Journal of the association of Nurses in AIDS care ;15(4):58-67.

Choksawadphinyo K (2005). Behaviors and barriers to self-care in people living with HIV/AIDS: Finding from a qualitative study in Northern Thailand .Asian Journal of Nursing; 8(3):31-38.

Country report on the Follow-up to the Declaration of Commitment on HIV/AIDS reporting period 20062007 UNGASS, National Aids Commission Republic of Indonesia, Jakarta 2008, Ref Type: Report

Directorate General CDC\&EH Ministry of Health, 2003

Directorate General CDC\&EH Ministry of Health, 2008. MOH annual report

Directorate General CDC\&EH Ministry of Health .2009. MOH annual report.

Flannelly LT \& Jillian I (2001). Relationship of religion, health status and socioeconomic status to the quality of life of individuals who are HIV positive. Issue in Mental Health Nursing; 22(3):253-27

Leenerts MH and Magilvy JK (1998). Investing in Self-care: Grounded in the lived experience of low-income VIV positive white women. Advanced Nursing Science; 22(3):58-75

Micek M A, Gimbel-Sherr K, Baptista AJ, Matediana E, Montoya P, Pfeiffer J, Melo A, Gimbel-Sherr S, Johnson W, and Gloyd S. (2009). Loss to FollowUp of Adults in Public HIV Care Systems in Central Mozambique: Identifying Obstacles to Treatment. J Acquir Immune Defic Syndr 2009;52:397-405.

Nachega, JB; Mugavero, MJ, Zeier, M; Vitória, M, Gallant, JE. 2011. Treatment simplification in HIVinfected adults as a strategy to prevent toxicity, improve adherence, quality of life and decrease healthcare costs. 
Patient Preference and Adherence 2011:5 357-367

National AIDS Committee (2008). Data Kasus 2005 - 2008. Available at: http://www.aidsindonesia.or.id/index. php?option=com_content\&task=view $\&$ id=1611\&Itemid $=124$

Pisani E, Dadun, Sucahya PK, Kamil O, Jazan S. Sexual behavior among injection drug users in 3 Indonesian cities carries a high potential for HIV spread to non-injectors. (2003) J Acquire Immune Defic Syndr 2003; 34(4):403406.

Riley T, Lewis BM, Lewis JF (2007). Lowincome HIV-Infected women and Process of engaging in Healthy Behaviour. Journal of the Association of Nurses in AIDS Care 2007; 19(1):315 .

Siegel K and Krauss BJ (2002). Living with HIV Infection. Journal of Health Social behaviour ;32:17-32.

UNAIDS. Epidemiological fact sheets on HIV/AIDS and sexually transmitted infections-Indonesia. 2006. Ref Type: Report

UNAIDS. AIDS epidemic update. 2007. Geneva. Ref Type: Report
Weigel R, Hochgesang $M$, Brinkhof $M$, Hosseinipour MC, Boxshall $M$, Mhango E, Nkwazi B, Tweya $\mathrm{H}$, Kamlaka M, Chagwera F, Phiri S. (2011). Outcomes and associated risk factors of patients traced after being lost to follow-up from antiretroviral treatment in Lilongwe, Malawi. BMC Infectious Diseases 2011, 11:31

Lumenta, B. (1997). Tanatologi tentang Perilaku Pasien Terminal. Ebers Papirus-Vol 3. No.1

Lonetto, R., \& Templer, D. ( 1991). Death Anxiety. Washington: Hemisphere Publishing Corporation.

Monks. (2011). Psikologi Perkembangan. Yogyakarta: Gadjah Mada University Pres.

Ross, K. E. (2011). Death and Dying. New York: Simon and Schuste.

Smeltzer \& Bare (2007). Brunner \& Suddarth's texbook of medical surgical nursing. Philadelphia: Lippincott Williams \& Wilkins.

Sugiyono. (2014). Metode Penelitian Kuantitatif dan kuantitatif. Bandung: Alfabeta.

Yuliana. (2015). Mengatasi Kecemasan terhadap Kematian pada Pasien Sakit melalui Konseling Kelompok. Seminar Psikologi \& Kemanusiaan , 458-463. 